\title{
Corporate Inversion: A Symbol Of A Changing Paradigm Of Corporate Behavior? Balancing Global Competitiveness, Fiduciary Duty, And Ethical Behavior \\ Novella Clevenger (zzclen@washburn.edu), Washburn University Martha Crumpacker (martha.crumpacker@washburn.edu), Washburn University Ray Siehndel (ray.siehndel@ washburn.edu), Washburn University
}

\begin{abstract}
Global competitiveness is affecting U.S Companies in a variety of ways. One is tax policy. U.S. federal tax policy in a global environment causes many U.S.-based companies to operate at a disadvantage to some foreign competitors. Current U.S. tax laws require domestic residents to pay income taxes on worldwide income. However, many countries have tax systems that exempt from domestic taxation profits earned by foreign subsidiaries. In addition, U.S. corporations with foreign-source income may be subject to tax by the country in which the income is earned. In an effort to eliminate this competitive burden, a growing number of U.S.-based companies have engaged in corporate inversion transactions. U.S.-based companies need to reconcile their fiduciary duty to shareholders with fundamental ethical issues as well as federal tax policy in justifying moving to another country solely for its beneficial tax system.
\end{abstract}

\section{Introduction}

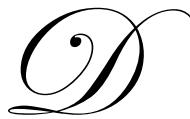

uring the past decade, corporate inversion among U.S.-based companies has become common in the business community. ${ }^{1}$ On the heels of public outcry over recent, large-scale corporate scandals, however, the practice of corporate inversion has sparked a spirited debate among congressional policymakers and others. ${ }^{2}$ This article highlights three perspectives underlying that debate: U.S. federal tax policy in a global competitive environment, fiduciary duty to shareholders, and ethics. Reconciling these perspectives presents a challenge that U.S.-based companies should acknowledge and affirmatively address to remain successful in an era of increasing public demands for transparency of corporate actions.

1 See, e.g., Treasury Sees Halt to Flight of U.S. Firms to Tax Havens, CONGRESS DAILY, Oct. 16, 2002.

Id. During a 2002 Treasury-Postal Appropriations Subcommittee hearing, discussion of corporate inversions illustrated the scope of the debate. Then Democratic Chairman, Byron Dorgan (D-N.D.) likened the reincorporation process to renouncing American citizenship and being unpatriotic. According to Dorgan, such companies "ought to rely on the [27 person] Bermuda navy" for protection instead of the United States. See also, Peter Meade, "A New Bermuda Triangle for U.S. Corporations," The Boston Globe (August 14, 2002). Similarly, the director of Citizens for Tax Justice viewed proposals to address corporate inversions as "watered-down" attempts at ending such off-shore reincorporations, while protecting the companies through a series of new loopholes. See supra, note 1. Conversely, a number of Republican conservatives, objected to placing limits on offshore companies as having "the smell of a tax increase to it." See Consensus on New Tax Package Remains Elusive, CONGRESS DAILY, Oct. 16, 2002. The U.S. Chamber of Commerce agreed that action to stem reincorporations would put U.S. companies at a competitive disadvantage against foreign companies. See supra note 1. Finally, the Assistant Treasury Secretary for Tax Policy expressed the need for caution, urging that any changes "be broad enough to address the underlying differences" between U.S. tax treatment of U.S.-based companies and foreign-based companies. Id. 


\section{Global Competitiveness}

\subsection{Tax Benefits Of Corporate Inversion}

A corporate inversion ${ }^{3}$ is a transaction whereby a U.S.-based company, through a vote of its shareholders, reincorporates in a country that has very low or zero corporate income taxes. In most cases, the location of the company's home office, operations, and employees does not change and there is little or no physical presence in the new country of incorporation. According to documents filed with the Security and Exchange Commission, reduction in taxes is frequently cited as the primary reason for corporate inversion transactions. ${ }^{4}$

Under current U.S. tax laws, domestic residents are taxed on world-wide income. In addition, U.S. corporations with foreign-source income may be subject to tax by the country in which the income is earned. Although foreign tax credit rules do exist to allow a company to offset the duplication of taxes on world-wide income, these laws are complex and not available on all types of income.

In contrast, many other countries have tax systems that exempt from domestic taxation any profits earned by foreign subsidiaries. Thus, U.S.-based companies are operating at a disadvantage in comparison with some foreign competitors. During the past few years in particular, efforts to eliminate this competitive burden have led a growing number of U.S.-based companies to engage in corporate inversion transactions. ${ }^{5}$

\subsection{Tax Consequences Of Corporate Inversion}

Although all corporate inversion transactions will have an immediate tax effect, either to the shareholders or to the company, the opportunities for long-term tax savings are considerable when accompanied by other restructuring steps or changes in future business operations (sometimes referred to as earnings stripping).

In some cases, the U.S.-based company transfers existing foreign subsidiaries to the new foreign parent, either through an exchange of stock or a transfer of assets. The effect of this type of transaction is to remove the income of the foreign subsidiaries from future U.S. taxation. Shareholders must recognize any gain on the exchange of stock, but due to recent market conditions, shareholders may actually have little or no gain to recognize. Companies may be able to offset gains at the company level by net operating losses. Concurrent with the inversion transaction may also be the creation of intercompany indebtedness, whereby the U.S. Company, now a subsidiary, borrows money from the new foreign parent. Such action permits the new U.S. subsidiary both to deduct interest payments, as well as reduce taxes owed on income earned from U.S. operations.

Another method commonly used to reduce U.S. taxes is for the U.S. subsidiary to transfer ownership of intangible assets, such as patents or the company name, to the new foreign parent. This action results in creating a deduction from U.S. income for royalties paid to the new foreign owner for use of the assets. Clearly, when the new foreign parent company is located in a country with zero taxation of domestic corporate income, the tax savings to the entity as a whole can be significant.

3 See generally, Lemein and McDonald, "Taxable Inversion Transactions," TAXES 7 (March 2002).

4 U.S. Department of the Treasury, Office of Tax Policy, "Corporate Inversion Transactions: Tax Policy Implications," May 2002, available at http://www.ustreas.gov/press/releases/docs/inversion.pdf.

5 Tim Reason, Love It and Leave It? The Hue-and-Cry Over inversions May Change the Way Overseas Income is taxed. CFO Magazine, July 30, 2002, available at_http://www.cfo.com/printarticle/0,5317,7376IA,00.html?f=options. Over the past decade, in order to reduce their tax burden, at least 20 U.S.-based companies have reincorporated outside the United States, most commonly in Bermuda and the Cayman Islands, as follows: 1994 (Helen of Troy); 1995 (Electric Mutual Liability Insurance); 1996 (Triton Energy, Tyco International); 1999 (Everest Reinsurance Holdings, Fruit of the Loom, PX Rd, TransOcean Sedco Forex, White Mountain Insurance Group, Xoma); 2000 (Applied Power); 2001 (Accenture, Foster Wheeler, GlobalSantaFe, Ingersoll-Rand); and 2002 (Cooper Industries, Nabors Industries, Noble, The Stanley Works, and Weatherford International). Id. In 2002, in an effort to stem the increase in corporate inversions, various legislators introduced bills in Congress. See supra note 4. During this same period of time, the U.S. Department of Treasury undertook a study of the implications of corporate inversions on the U.S. tax system and economy. Id. In May 2002, the Treasury Department released a preliminary report "[i]n the interest of providing technical and analytical input to the ongoing consideration of an appropriate response to this inversion activity." Id. at 3. 


\subsection{Effect Of Corporate Inversion On Business Operations}

In most instances, a corporate inversion results in no noticeable change in company operations. ${ }^{6}$ The stock of the new foreign parent may continue being traded on the U.S. stock exchange, often using the same ticker symbol. Moreover, companies may continue to be members of the S\&P 500 if the companies are still considered to be domestic corporations for that purpose. Companies that have successfully undergone corporate inversion may also realize an ability to raise capital from foreign investors more readily than before the inversion, as dividends from the new foreign parent will no longer be subject to the U.S. withholding tax.

\subsection{Other Tax Reduction Strategies For U.S.-Based Companies}

The benefits available through corporate inversion are not solely the result of corporate inversion. ${ }^{7}$ Companies may realize such benefits through other methods. For instance, a U.S.-based start-up company can be incorporated in a foreign country at the beginning of its start-up. Also, in an increasingly popular alternative, an existing U.S.-based company can be the subject of a takeover, either hostile or friendly, by a foreign-based company. Perhaps it is no coincidence that foreign acquisitions of U.S. businesses increased from $\$ 90.9$ billion in 1997 to $\$ 340$ billion in $2000 .^{8}$

\subsection{U.S. Tax Policy Considerations}

The U.S. international tax system dates to the 1960s. At that time, the United States was without a doubt the single-most dominant economic force in global business. Over time, however, other countries have become major forces in the global business community. Because foreign-based companies are better able to pass tax savings to customers, U.S.-based companies have experienced competitive pressure to lower taxes. As a result, the existing U.S. tax base may face a risk of substantial erosion over time. That, in turn, may result in reduced confidence in the tax system and negatively impact voluntary compliance or raise related issues. Other taxpayers, unwilling to assume the additional tax burden of abdicating U.S.-based companies may devise their own tax-reduction strategies, including, arguably, some strategies of questionable legality.

On June 25, 2002, during the House Ways and Means Committee Select Revenue Measures Subcommittee Hearing on Corporate Inversions, the American Institute of Certified Public Accountants (AICPA) presented its position on the corporate inversion debate. ${ }^{9}$ The AICPA statement emphasized that congressional response should focus not on stopping corporate inversions, but rather on the incentives for corporations to invert. Specifically, the AICPA stated its belief "that the U.S. tax treatment for multinational groups with a U.S. parent corporation should be at least as favorable as that for multinational groups with a foreign parent." 10 The AICPA statement also warned of possible "negative effects on the U.S. economy, such as potentially encouraging the takeover of U.S.-based companies by foreign acquirers." 11

Several months later, on October 16, 2002, during the Senate Appropriations Subcommittee on Treasury and General Government Hearing on Corporate Inversions, the Assistant Secretary of Tax Policy, U.S. Department of the Treasury voiced similar concerns. In prepared testimony, the Assistant presented an overview of the Treasury Department's report on the tax policy implication of corporate inversion transactions. ${ }^{12}$ The report promoted the need for "a comprehensive reexamination of the U.S. international tax rules and the economic assumptions underlying them." 13 The Assistant Secretary stated, "[a]s we consider the appropriate reformulation of these rules

6 See supra, note 4.

7 Id.

8 Id.

9 Pamela J. Pecarich, Comments for the Record of the June 25, 2002 House Ways and Means Committee Select Revenue Measures Subcommittee Hearing on Corporate Inversions, Letter to The Honorable Jim McCrery, Chair, Subcommittee on Select Revenue Measures, June 28, 2002, available at http: //www.freedomandprosperity.org/ltr/ aicpa/aicpa.shtml.

10 Id. at 2.

11 Id.

12 See supra note 4.

13 See Statement of Pamela Olson, Assistant Secretary (Tax Policy), United States Department of the Treasury, Before the Senate Appropriations Subcommittee on Treasury and General Government (Oct. 16, 2002). 
we should not underestimate the benefits to be gained from reducing the complexity of the current rules. Our system of international tax rules should not disadvantage U.S.-based companies competing in the global marketplace." ${ }^{\prime 4}$ In addition, however, the Assistant Secretary, on behalf of the Treasury Department, extended the consideration of new tax policy to include a need to "focus on the overarching goal of maintaining the attractiveness of the United States as the most desirable location in the world for incorporation, headquartering, foreign investment, business operations, and employment opportunities, to ensure an ever higher standard of living for all Americans." 15

\section{Fiduciary Duty To Shareholders}

One view of the U.S. Department of the Treasury testimony is that it presents a multi-prong policy approach for addressing the issue of corporate inversions in an effort to calm the growing tension between traditional views of corporate accountability to shareholders and rapidly increasing public expectations for corporate accountability to the community at large. Such a view is plausible, given the number of high-profile corporate collapses and corporate scandals during the recent past resulting in a breakdown in trust between the public and the business community. ${ }^{16}$

General criticism and characterization of corporate executives' actions in relation to the practice of corporate inversion transactions have fallen along a descriptive continuum of type of "bad decision," ranging at the very least, from unpatriotic, to, at worst, criminal. ${ }^{17}$ Whether such criticism is warranted depends upon whose interests are being served -- and whose interests should be served - - the shareholders, corporate management and directors, or the interests of society as a whole. What remains clear, however, is that the existing tension may indeed be indicative that a change in the overall paradigm of corporate behavior is imminent.

In an attempt to restore the public's confidence and to increase the transparency of corporate actions in general, Congress enacted the Sarbanes-Oxley Act of 2002. ${ }^{18}$ Similarly, at the state level, public outcry has fueled passage of state legislation to increase corporate responsibility. ${ }^{19}$ If the current congressional debate over corporate inversions is a signal that more sweeping change is indeed underway, the Treasury Department's proposed policy parameters would require a significant shift away from the traditional corporate paradigm whereby existing law mandates that when the choice is between the public good and the good of the corporation, corporate management must act in the corporation's best interest.

\subsection{Fiduciary Duty To Shareholders}

In our society, the rule of law governs American business. Traditional corporate law holds that because shareholders of a company own the company, corporate officers' and directors' fiduciary duties require actions that result in maximum return on investment for the company's owners/shareholders. Anything less would arguably be a breach of fiduciary duty increasing officers' and directors' vulnerability to possible litigation. Similarly, current tax law permits corporate inversion. Since keeping taxes as low as possible is a business variable that may enhance a company's ultimate return on investment, corporate management arguably must consider inversion transactions if so doing would be in the shareholders' best interest.

\footnotetext{
${ }^{14}$ Id. at 30 .

${ }^{15}$ Id.

${ }^{16}$ See, e.g., What We Believe: Minnesota Business Leaders Speak Out, Center for Ethical Business Cultures, Star Tribune Business Forum, April 13, 2003, available at http://www.cebcglobal.org/Newsroom/News/News_041303.htm.

${ }^{17}$ Daniel J. Mitchell, Ph.D., Corporate Expatriation Protects American Jobs, Executive Memorandum \#829, August 29, 2002, available at http://www.heritage.org/Research/Taxes/em829.cfm.

18 P.L. 107-204, enacted July 30, 2002, after passage in the Senate by a 99-0 vote and in the House of Representatives by a 423-3 margin. Support for the Sarbanes-Oxley Act of 2002 was fueled by accounting scandals, such as Enron, et al. The Act establishes new governance rules for corporations and accountants.

${ }^{19}$ See, e.g., John Moran, Corporate Responsibility Legislation in Connecticut and Other States, August 9, 2002, available at http://www.cga.state.ct.us/2002/olrdata/lab/rpt/2002-R-0710.htm (discussing corporate responsibility legislation in the states of Connecticut, Minnesota, Maine, and West Virginia).
} 
Continued corporate failures, however, have called into question the standards by which corporate officers and directors are seeking to "maximize shareholder value." 20 Media coverage of corporate failures often conclude that lack of operational standards and oversight represent "failures in corporate governance and integrity." Clearly, if following the "spirit of the law" promotes actions geared at realizing maximum monetary results, following the "letter of the law" must require adherence to rules geared at promoting and maintaining consumer confidence in the system.

\subsection{Corporate Governance}

Corporate governance is a concept whereby a company sets forth the rules by which officers, directors, and employees will conduct business. The Cadbury Report ${ }^{22}$ defines corporate governance as:

...the system by which business corporations are directed and controlled. The corporate governance structure specifies the distribution of rights and responsibilities among different corporate participants in the corporation, such as, the board, the managers, shareholders and other stakeholders, and spells out the rules and procedures for making decisions on corporate affairs. By doing this, it also provides the structure through which the company objectives are set, and the means of attaining those objectives and monitoring performance. ${ }^{23}$

Shinn $(2001)^{24}$ suggests that an organization's governance system is comprised of four key features: Information institutions (accounting rules, audit procedures, standards settings, and third-party analysis); ${ }^{25}$ Oversight institutions (boards of directors and the rules governing their fiduciary responsibilities); ${ }^{26}$ Control institutions (the degree of voice minority shareholders have in case of contested control and the rules which govern such contests); ${ }^{27}$ and Managerial institutions (hiring, compensating, and firing of senior managers). ${ }^{28}$ The influence of each of these features can lead to and will affect the distribution of power within different models of corporate governance. ${ }^{29}$ These models differ in the way a company designs and implements its control and reward systems. ${ }^{30}$ Although U.S.-based companies are not statutorily subject to a universal, common code of conduct, effective corporate governance must begin with and have the full support of the board of directors. ${ }^{31}$

${ }^{20}$ See Corporate Responsibility, July 17, 2002, available at http://law.about.com/library/weekly/aa071702a.htm. According to business consultant Peter J. Clark, the phrase "maximize shareholder value" is one of the "enduring mantras of the business world." Id.

${ }^{21}$ See supra note 16.

22 See, Deborah Orr, Maxwell's Ghost - Britain Found a Better Way to Rein in Rogue Managements, Forbes.com, September 9, 2002, available at http://www.forbes.com/global/2002/0902/044_print.html. The Cadbury Report is a U.K.-commissioned study arising from corporate failures during the late 1980s and early 1990s similar to the recent U.S. experiences with Enron, Tyco, and WorldCom. Id. The report is widely accepted as one of the first and most comprehensive efforts at developing a code of conduct and behavior to corporate behavior. Id. Numerous other countries have adopted the Cadbury Report recommendations as a model for a common code for the conduct of board members and auditors. Id. See also, supra note 18 (enactment of the Sarbanes-Oxley Act of 2002 establishing certain governance rules for corporations and accountants).

${ }^{23}$ Barwick, Gregg, Associate Lawyer, Ozannes, "Corporate Governance in An Offshore Context," May 2, 2003 available at http://www.pzannes.com/articles/Corporate_Governance_for_NLJ_2003.pdf.

${ }^{24}$ Shinn, James J., GLOBALIZATION, CORPORATE GOVERNANCE AND THE STATE: TESTING CONVERGENCE IN TWELVE COUNTRY SAMPLE, Ph.D. Dissertation (Princeton 2001).

${ }^{25}$ Id. at 32.

${ }^{26}$ Id. at 36 .

${ }^{27}$ Id. at 37 .

${ }^{28}$ Id. at 38.

29 See, e.g., CORPORATE RESPONSIBILITY AND CORPORATE COMPLIANCE: A Resource for Health Care Boards of Directors, April 2, 2003, by the Office of Inspector General, Department of Health and Human Services and the American Health Lawyers Association (providing guidance to boards of directors of health care entities on how to meet their fiduciary responsibilities of compliance oversight, including a director's duty of care).

${ }^{30}$ For example, during the grand-jury investigation of Enron, information emerged that characterized Enron's control and reward system as "a Wild West culture that sublimated everything to the goal of driving up the stock price." See, e.g., Heesun Wee, Corporate Ethics: Right Makes Might, April 11, 2002, Business Week Online, available at http://www.businessweek.com:/print/bwdaily/dnflash/ apr2002/nf20020411_6350.htm?gb. Enron "hired . . from top schools, and the perennial question among colleagues seemed to be, 'Can you make the deal?' . . If you're really a clever person, you make the deal. If you're not clever, you're going to work for [rival] Reliant or Duke because you're not going to last long." Id.

${ }^{31}$ See A New Ethic of Corporate Responsibility, President George W. Bush, The White House, July 9, 2002, available at http://www.whitehouse,gov/news/releases/2002/07/print/20020709.html. To underscore the importance of support from the highest level, last year, President George Bush formally announced an initiative entitled "A New Ethic of Corporate Responsibility," which, among other things, challenged CEOs "to comply with the spirit of existing disclosure rules;" proposed provisions to strengthen the power or jurisdiction of the 


\subsection{Corporate Responsibility}

Traditional corporate law "requires corporate officers and directors to act in the best interest of their corporation, not the public at large." 32 Increasingly, however, commentators are promoting the need to extend the tenets of corporate law to include a duty for corporate officers and directors to limit corporate actions geared at maximizing shareholders' return on investment if such actions result in an adverse effect on the community at large. ${ }^{33}$ In a survey of more than 1000 adults conducted by Business Week/Harris Poll during 2000, only 4 percent agreed with the statement that "U.S. corporations should have only one purpose - to make the most profit for their shareholders - and their pursuit of that goal will be best for America in the long run." 34 Conversely, 95 percent agreed with the statement that "U.S. corporations should have more than one purpose. They also owe something to their workers and the communities in which they operate, and they should sometimes sacrifice some profit for the sake of making things better for their workers and communities." 35

The support or promotion of a corporate responsibility approach necessarily requires U.S. companies to embrace or reject certain social and political philosophies and create ambiguous litmus screens that, according to some, place corporate officers and directors on an unavoidable collision course of conflict with their fiduciary duty to shareholders. ${ }^{36}$ From a global competitive perspective, companies singled out for lapses in corporate responsibility may respond with marketing campaigns or internal codes of conduct that they, themselves acknowledge serve essentially as "balm to consumers," but result in, at best, only incremental actual change. ${ }^{37}$ In the case of Enron, for example, employees signed a code of conduct upon joining the company. During 1999, however, the Enron board of directors, suspended its company code twice to permit a top Enron executive to lead outside partnerships, even though the executive would gain financially from the ventures. ${ }^{38}$

Finally, notwithstanding results of surveys and short of a fundamental shift in corporate philosophy, when faced with issues such as whether to engage in corporate inversion transactions, the Treasury Department's suggested policy approach to corporate inversions may ultimately require consideration of a company's corporate conscience.

\section{Ethical Behavior}

"Ethics, like democracy, is a lot easier in theory than in practice." ${ }^{39}$ While sharing some of the general tenets of the corporate responsibility movement, the corporate ethical movement focuses primarily on behavior, from top management on down, throughout the company.

Securities and Exchange Commission; and established, by Executive Order, a Corporate Fraud Task Force "to provide direction for investigations and prosecutions of criminal activity." Id. This initiative also bolstered the President's previously-announced comprehensive corporate reform agenda. Highlights of the reform agenda include: exposing and punishing acts of corruption; holding corporate officers more accountable; protecting small investors and pension holders; moving corporate accounting out of the shadows; developing a stronger and more independent corporate audit system; and providing better information to investors. Id.

${ }^{32}$ See supra note 20.

${ }^{33}$ Id. One author, Marjorie Kelly (THE DIVINE RIGHT OF CAPITAL), advocates creating "a broad duty of loyalty in law to the public good." Id. Kelly would require that corporate officers and directors not pursue a course of action geared at maximizing shareholder value "at the expense of the community, the employees, or the environment." Id. Others, however, discount Kelly's proposals as "superficially appealing" and unworkable because "[i]n the business world, which is far less regulated than the practice of law, who is to say whether a particular policy harms the community, the employees or the environment?" Id.

${ }^{34}$ See Business Week/Harris Poll: How Business Rates: By the Numbers, BusinessWeek Online, September 11, 2000, available at http://www.businessweek.com:/2000/00_37/b3698004.htm?scriptFramed.

${ }^{35}$ Id.

36 Jon Entine, Corporate Ethics and Accountability, At Work, September/October 1996, available at http:// www.corpgov.net/forums/commentary/entine1.html.

${ }^{37}$ Id. For instance, in 1994, because of its high public profile, labor activists targeted the popular coffee retailer Starbucks for sourcing coffee beans from Guatemala where workers earned less than a living daily wage. In response, Starbucks passed a code of conduct promising to review plantation conditions. Id. The reviews were to be conducted by the very association initially accused of not paying workers a living daily wage. Id. Although Starbucks admitted that actual improvements would be incremental at best and that it had taken no actual action, the company was later recognized with the International Human Rights Award by the Council on Economic Priorities at its annual "Corporate Conscience" awards ceremony. Id.

${ }^{38}$ See supra, note 30 .

${ }^{39}$ See supra, note 36. 


\subsection{Corporate Executive Behavior}

In a 2003 survey conducted by the Ethics Resource Center ${ }^{40}$ of 1500 workers questioned across the nation, "the perception that top management keeps promises and commitments to the employees rose to 82 percent ... compared to 77 percent" in $2000 .{ }^{41}$ However, only " 21 percent of managers under 30 feel pressure to compromise on company ethics standards, compared to 9 percent of all managers." 42 The message is clear, employees take note whether top management actually "walks the walk," or simply "talks the talk" and acts accordingly. Put another way, "people at the top tend to set the target, the climate, the ethos, the expectations that fuel behavior." ${ }^{43}$

Responsible behavior is reflected through acting intelligently, i.e. carefully weighing the benefits and harm that one's own personal actions can bring. Moral behavior occurs on the basis of a balance between the realization of interests and the avoidance of physical, social, or even state sanctions. The importance of ethics is shown in the fact that most people choose to maximize their own benefits when economic and political decisions have to be made. ${ }^{44}$ To do what is "legally correct" may be deficient of any moral base. In other words, an action can be legal, but it still can be morally wrong ${ }^{45}$

A widely touted example of a company promoting ethical action over potential shareholder gain is Johnson \& Johnson during the Tylenol scare of the 1980s: ${ }^{46}$

[W] hen the Tylenol scare hit . . and seven Chicago residents died after ingesting cyanide-laced capsules, J\&J managers knew what they had to do - even without consulting with then-CEO James Burke, who was on a plane as the news broke. By the time Burke landed and caught up with his top managers, they already had called for all Tylenol products to be pulled off shelves and for production of all Tylenol items to be halted. The J\&J managers ignored advice from consultants and attorneys who had argued such dramatic steps might harm the Tylenol brand and imply the contamination was the work of a $J \& J$ employee. 'In the end, it was a joint consensus agreement around the company's values, the No. 1 value being that the health of our customers comes first before anything else, including stockholder value. ${ }^{, 47}$

\subsection{Patriotism}

According to Thomas M. Jones, in the Chicago office of McDermott, Will \& Emory, current tax rules create "a major disparity between what is right for the country and what is right for [the] company." 48 "We should strive to achieve a tax system that aligns patriotism with good business sense. That is the [real] challenge that Congress needs to take on."49

Since the terrorist attacks of September 11, 2001, companies have faced both economic challenges as well as challenges related to the country's heightened sense of patriotism and unity. Expatriations, such as that of Ingersoll-Rand Co. ${ }^{50}$ within weeks or months of the World Trade Center collapse generated unprecedented bipartisan congressional ire. ${ }^{51}$ Not long after, a number of legislators introduced or co-sponsored bills to stem the

\footnotetext{
${ }^{40}$ See C. Benjamin Ford, Corporate Ethics on Rise, Report Says, May 23, 2003, available at http://www.gazette net/200321/business/news/160098-1.html.

41 Id.

42 Id.

43 See supra, note 30 (quoting Thomas Donaldson, professor of business ethics at the Wharton School of Business, University of Pennsylvania).

${ }^{44}$ See generally, Klaus M. Leisinger, Corporate Ethics and International Business: Some Basic Issues, Hong Kong, June 2nd, 1994, available at http://www.novartisfoundationcom/business_corporate_ethics_print.htm.

45 Harold S. Peckron, Watchdogs That Failed to Bark: Standards of Tax Review After Enron Florida Tax Review, 5 Fla. Tax Rev. 851, 2002.

46 See supra, note 30 .

47 Id.

48 Tim Reason, Love It and Leave It? The Hue-and-Cry Over inversions May Change the Way Overseas Income is Taxed. CFO Magazine, July 30, 2002, available at http://www.cfo.com/printarticle/0,5317,7376I!A.00,html?f= options.

49 Id.

50 Id.

51 Id. Senator Charles Grassley (R-Iowa), then ranking member of the Senate Finance Committee, charged, "It's outrageous that some companies are willing to leave their country during a war and a recession just to save some taxes." Id.
} 
practice of corporate inversions. ${ }^{52}$ Aside from questions of technical compliance with the law, whether corporate expatriation in order to reduce a tax liability is unethical or unpatriotic depends upon one's perspective, and, in the case of Congress, the perspective of one's constituents. ${ }^{53}$

\subsection{Fairness}

Finally, considering corporate inversion in light of suggested broadening of U.S. tax policy from an ethical perspective, one should not neglect the competitiveness issue involving corporate inversion as seen through the eyes of a small or midsize business trying to compete with a large U.S.-based company that, through inversion, avoids U.S. taxation by stripping out any U.S. earnings. People who own and or work for small and mid-size business are at an immediate disadvantage with respect to competitiveness as such small businesses are not eligible for a $10 \%$ effective reduction in tax rates because they cannot engage in corporate inversion. ${ }^{54}$

\section{Summary}

Corporate inversion is a creature of U.S. laws - from tax laws that put U.S.-based companies at a disadvantage with international competitors to corporate governance laws that require corporate managers to maximize shareholder profits at the expense of the public interest. Public perception of companies that have engaged in corporate inversion transactions, particularly since the events of September 11, 2001, have fueled public outcry and congressional debate. Politicians of both parties are expected to use the issue during the upcoming presidential and congressional elections.

Public debate over the efficacy of corporate inversions offers opportunities for U.S.-based companies to evaluate the issue of changing U.S. federal tax policy from at least three perspectives: competitiveness in a global environment; fiduciary duty to shareholders (including corporate governance and corporate responsibility); and ethics (including patriotism and fairness). Reconciling these perspectives is a challenge that U.S.-based companies must be prepared to acknowledge and address to remain successful in an era of increasing public demands for transparency of corporate actions.

Congress should review existing tax laws with an eye towards assisting U.S.-based companies to compete more effectively in the global marketplace. State Legislatures should modernize corporation law statutes to provide more leeway for management to consider effects of company policy on stakeholders other than their shareholders. And, large institutional investors must consider putting more pressure on large corporations to keep company headquarters and operations in the U.S. Finally, within an environment of unprecedented patriotism and unity, countered by a wave of corporate scandals, shareholders, officers, and directors may enhance corporate image and improve business profits in the long run by promoting ethical corporate behavior in relation to the decision-making process of whether to engage in corporate inversion transactions.

\footnotetext{
${ }_{53}^{52}$ See, e.g., supra, note 4, for a listing of congressional leaders and the legislation they introduced to address corporate inversions.

53 Notwithstanding the legality of the practice, with a presidential election cycle in the process of gearing up, both Republicans and Democrats are likely to use corporate inversion as a political issue. See, e.g., Mike Allen, Bush Faces Questions on Offshore Affiliates, Washingtonpost.com, August 1, 2002, available at http://www.washingtonpost.com/ac2/wp-dyn/A28291-2002Jul31?language=printer (reporting that companies connected to President Bush and to Vice President Cheney had engaged in corporate inversion transactions).

${ }^{54}$ See McInnis Opening Statement on Corporate Inversions, press release, Representative Scott McInnis (R-CO), June 6, 2002, available at http://www.house.gov/mcinnis/pr020606a.htm.
} 